\title{
ANALISIS KESIAPAN PETANI KELAPA SAWIT SWADAYA DALAM PENERAPAN ISPO DI KABUPATEN INDRAGIRI HILIR
}

\author{
Yusmini ${ }^{1}$, Heriyanto ${ }^{2}$ \\ Program Studi Agribisnis \\ Fakultas Pertanian, Universitas Islam Riau \\ J1. Kaharuddin Nasution 113 Perhentian Marpoyan Pekanbaru-Riau \\ email : minyagb1@yahoo.co.id \\ heriyanto@agr.uir.ac.id
}

\begin{abstract}
Abstrak
Penelitian ini bertujuan untuk mengidentifikasi dan menganalisis kesiapan petani swadaya kabupaten Inhil dalam penerapan ISPO. Analisis data dilakukan secara analisis deskriptif kuantitatif dengan dengan membandingkan pelaksanaan legalitas, organisasi dan pengelolaan, pengelolaan dan pemantauan lingkungan yang diterapkan oleh petani swadaya, apakah sudah sesuai dengan prinsip, kriteria dan indiKator ISPO. Kesiapan penerapan ISPO pada petani sawdaya dengan melakukan penilaian terhadap empat prinsip, 20 kriteria dan 47 indikator. Dari 47 indikator yang ditetapkan pada persayaratan ISPO pola swadaya, sebanyak 48,94\% indikator ISPO belum pernah dijalankan petani swadaya dan sebesar 51,06 \% indiKator ISPO sudah ada petani yang menjalananya. Dari indikator ISPO yang sudah dijalankan petani swadaya, hanya dijalankan oleh sebahagian kecil petani swadaya, dimana dari seluruh indikator yang sudah dijalankan ini hanya dijalan oleh $10 \%$ sampai $19,15 \%$ petani swadaya.
\end{abstract}

Kata kunci: ISPO, Kelapa Sawit, Swadaya.

\section{PENDAHULUAN}

Tanaman kelapa sawit merupakan salah satu komoditi unggulan perkebunan di Indonesia, dimana kelapa sawit memiliki fungsi ganda, selain mempunyai fungsi ekonomis yang relatif tinggi, juga mampu meningkatkan fungsi sosial dan ekologi. Fungsi ganda kelapa sawit sehingga membuat Indonesia mendominasi pasar sawit dunia, kurang diiringi dengan manajemen pengelolaan perkebunan sawit yang baik atau manajemen pengelolaan kebun kelapa sawit Indonesia belum ideal, sehingga banyak tudingan miring, khususnya lembaga manca negara terhadap sektor perkebunan kelapa sawit Indonesia. Tudingan tersebut bisa dikatakan atau dilatar belakangi, karena Indonesia saat ini adalah negara utama penghasil komoditi kelapa sawit, keberhasilan Indonesia menjadi produsen utama minyak kelapa sawit, suatu hal yang wajar jika menghadapi tantangan , dimana berbagai isu negatif dilontarkan negara-negara penghasil minyak nabati non sawit, terhadap minyak sawit Indonesiav (Sucipto, 2011).

Pemerintah Indonesia melalui Kementerian Pertanian, meredam tudingan negatif tersebut dengan memberikan sertifikat Indonesia Sustainable Palm Oil (ISPO) kepada usaha /pelaku kelapa sawit di Indonesia, ISPO diharapkan menghindari dan mengurangi dampak pengrusakan lingkungan, emisi gas rumah kaca, hingga pemicu deforestasi(seperti yang di sampaikan lembaga mancanegara). Walaupun ditigkat internasional sudah ada Rountable Sustainable Palm Oil (RSPO), tapi Indonesia menetapkan ISPO, karena Sertifikasi internasional RSPO bersifat voluntary, untuk memenuhi permintaan pasar. ISPO bersifat mandatory atau wajib dan akan ada sanksi bagi perusahaan yang tidak melakukan/memiliki sertifikasi ISPO.

Di Indonesia ada tiga pola pengelolaan perkebunan kelapa sawit yaitu perusahaan, plasma dan swadaya. Swadaya adalah pola pengembangan perkebunan kelapa sawit yang dilakukan oleh petani sendiri, mulai dari pembukaan lahan, penanaman, pemeliharaan, panen pemasaran hasil tanpa melalui kemitraan usaha. Pola pengelolaan swadaya merupakan luas lahan yang paling luas dari tiga pengelolaan kebun kelapa sawit yang ada di Indonesia, dan kebun pola swadaya ini mengalami peningkaatan terus. Peningkatan luas lahan pola swadaya tidak seimbang dengan 
peningkatan produktivitasnya, dimana produktivitas pola swadaya lebih rendah dari perusahaan besar, produktivitas pola swadaya hanya sekitar 2,5 sampai 3 ton per hektar, sedang perkebunan besar swasta sekitar 3,5 sampai 4 ton per hektar (Komisi ISPO, 2014).

Kabupaten Indragiri Hilir sama halnya dengan kondisi di Indonesia umumnya, dimana juga terdapat 3 pola pengelolaan kebun kelapa sawit. Luas lahan pengelolaan pola swadaya, juga merupakan yang terluas dari dua pola lainnya. Kondisi geografis Indragiri hilir yang terdiri dari daaerah dengan tipologi daratan, pasang surut dan pesisir, dimana luas lahan yang besar adalah yang bertipologi rawa(pasang surut) dan pesisir. Kondisi tipologi daerah Inhil ini menyebabkan produktivitas yang rendah, kualitas buah yang rendah, letak kebun yang terpencar dengan sarana jalan yang rusak dan biaya angkut yang tinggi serta rantai pemasaran yang panjang menjadikan harga jual TBS yang diterima petani swadaya jauh lebih rendah dibanding petani pola PIR. Hasil kajian Hadi, ddk (2008 dan 2010) mendapatkan bahwa rata-rata pendapatan kotor petani swadaya hanya sebesar Rp 550.000/ hektar, jauh lebih rendah dibanding petani plasma yaitu sebesar Rp 1.265.000/hektar.

Disisi lain, tekanan internasional terus menerpa ekspor minyak kelapa sawit yang selalu dikaitkan kebakaran lahan, pembabatan hutan, dan pemanasan global sebagai akibat pembukaan lahan gambut. Produksi minyak sawit yang sesuai dengan RSPO dan ISPO semakin menguat. Oleh karena itu, sebelum permasalahan pengembangan perkebunan kelapa sawit rakyat pola swadaya terus berkembang, maka perlu dilakukan analissis kesiapan petani swadaya dalam penerapan ISPO.

Berdasarkan uraian diatas penelitian bertujuan untuk mengidentifikasi dan menganalisis penerapan ISPO ditingkat petani swadaya di Indragiri Hilir.

\section{KAJIAN PUSTAKA}

Penerapan ISPO merupakan implementasi dari Peraturan Menteri Pertanian (Permentan) Nomor 19/Permentan/OT.140/3/2011, tentang Indonesia Sustainable Palm Oil (ISPO). Penerapan ISPO sekaligus menjadi upaya agar dapat meningkatkan posisi tawar CPO (crude palm oil/minyak mentah sawit) Indonesia di pasar internasional. Penerapan ISPO bagi usaha perkebunan merupakan salah satu prasyarat untuk mewujudkan perkebunan berkelanjutan yang mensinergikan aspek ekonomi, sosial budaya dan ekologi. Keberhasilan pelaksanaan ISPO memerlukan dukungan dari semua komponen dan stakeholder (pemangku kepentingan), yang terkait dengan pembangunan usaha perkebunan kelapa sawit.

Sertifikasi ISPO tidak lepas dari Penilaian Usaha Perkebunan yang dilakukan oleh pemerintah (Sesuai dengan Permentan no. 07/Permentan/OT.140/2/2009 tentang pedoman penilaian usaha perkebunan). Di mana hasil penilaiannya adalah: Class I (sangat baik), Class II (baik), Class III (cukup), Class IV (kurang) and Class V (kurang sekali). Hanya Kelas I, II dan III yang bisa mengajukan aplikasi untuk mendapatkan sertifikat ISPO.Penerapan ISPO memiliki tujuan untuk (1) meningkatkan kepatuhan pelaku usaha perkebunan dalam menerapkan peraturan perundangan yang berlaku, (2) melindungi dan mempromosikan minyak sawit berkelanjutan Indonesia agar dapat diterima pasar internasional, (3) mendukung komitmen Indonesia dalam pelestarian sumber daya alam dan fungsi lingkungan hidup.

Menurut Rosediana (2013), Sekretariat Komisi Minyak Sawit Berkelanjutan Indonesia saat presentasi dalam Workshop Wartawan Nasional "Membangun Industri Kelapa Sawit Berkelanjutan 2013" yang digelar GAPKI . Setidaknya ada tiga tujuan utama ISPO, (1), meningkatkan kesadaran pengusaha/pelaku kelapa sawit Indonesia untuk memperbaiki linkungan. (2), meningkatkan daya saing minyak sawit Indonesia di luar negeri. (3), mendukung program pengurangan gas rumah kaca dan menjadi persyaratan utama negara pembeli bagi plam oil biodesel.

Peraturan perkebunan kelapa sawit di Indonesia pada dasarnya telah menerapkan prinsipprinsip pembangunan perkebunan berkelanjutan yang mendasarkan pada tiga aspek yaitu lingkungan, ekonomi dan sosial atau dikenal juga dengan 3P (People, Planet and Profit). Memenuhi tuntutan pembangunan berkelanjutan dan merespon tuntutan pasar global, pemerintah Indonesia menyiapkan 
Pedoman Perkebunan Kelapa Sawit Berkelanjutan Indonesia (Indonesian Sustainable Palm Oil / ISPO). ISPO merupakan acuan pengembangan kelapa sawit berkelanjutan Indonesia, yang merupakan rangkuman dari seluruh peraturan perundangan yang terkait dengan kelapa sawit yang berlaku di Indonesia, sehingga ketentuan ISPO merupakan ketentuan yang wajib dipatuhi oleh pelaku usaha perkebunan di Indonesia. Penerapan ISPO juga merupakan bukti kepatuhan pelaku usaha perkebunan, dalam memenuhi peraturan perundangan yang berlaku di Indonesia serta menerapkan prinsip pengelolaan perkebunan kelapa sawit berkelanjutan.

\section{METODE PENELITIAN}

Penelitian ini menggunakan metode survey, sedangkan unit analisis pada kajian ini adalah petani kelapa sawit swadaya. Sampel pekebun kelapa sawit rakyat diambil secara proporsional berdasarkan perkembangan areal kelapa sawit menurut kategori (tinggi, sedang, rendah). Kecamatan dengan perkembangan areal dengan kategori tinggi yaitu Keritang, Kemuning dan Kempas seluas 74.172 hektar atau $69,08 \%$ dari total areal perkebunan kelapa sawit rakyat di Indragiri Hilir dengan jumlah petani sebanyak 206.032 petani atau $69,08 \%$. Kecamatan dengan perkembangan areal dengan kategori sedang yaitu Gaung, Reteh dan Tempuling seluas 14.979 hektar atau 13,95\% dari total areal perkebunan kelapa sawit rakyat di Indragiri Hilir dengan jumlah petani sebanyak 86.306 petani atau $28,94 \%$. Kecamatan dengan perkembangan areal dengan kategori rendah yang diwakili oleh Pelangiran, Batang Tuaka dan Concong seluas 18.222 hektar atau $16,97 \%$ dari total areal perkebunan kelapa sawit rakyat di Indragiri Hilir dengan jumlah petani sebanyak 5.919 petani atau 1,98\%. Jumlah Petani di Primary Area (Kecamatan) sebanyak 79.290 KK. Jumlah sampel yang mencandrakan populasi dari 3 kategori di 9 kecamatan primary area, sebanyak 100 petani, dengan menggunakan rumus Slovin (Prasetyo dan Jannah, 2011) sebagai berikut:

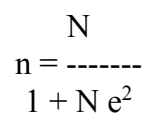

Dimana:

$$
\begin{aligned}
& \mathrm{n}=\text { Ukuran sample } \\
& \mathrm{N}=\text { Ukuran Populasi } \\
& \mathrm{E}=\text { error tolerance }(0.1)
\end{aligned}
$$

\section{Analisis Data}

Analisis data untuk menjawab tujuan mengidentifikasi kesiapan penerapan ISPO ditingkat petani di Indragiri Hilir, dilakukan dengan analisa deskriptif kuantitatif, dengan membandingkan pelaksanaan legalitas, organisasi dan pengelolaan, pengelolaan dan pemantauan lingkungan yang diterapkan oleh petani swadaya, apakah sudah sesuai dengan prinsip, kriteria dan indikator ISPO. Kesiapan penerapan ISPO pada petani sawdaya dengan melakukan penilaian terhadap empat prinsip, 20 kriteria dan 47 indikator.

\section{HASIL DAN PEMBAHASAN}

Untuk melihat kesiapan petani pola swadaya dalam menghadapi penerapan ISPO, dengan menganalisis kondisi petani pola swadaya berdasarkan prinsip, kriteria dan indikator yang sudah ditetapkan secara nasional.

\section{Prinsip Legalitas Kebun Petani Swadaya}

Prinsip legalitas kebun petani swadaya terdiri dari (a) kriteria legalitas kebun, (b) kriteria lokasi kebun petani swadaya. Kriteria legalitas kebun terdiri dari empat indikator dan kriteria 
lokasi kebun dua indikator. Untuk lebih jelasnya nilai masing-masing indikator pada prinsip legalitas kebun dapat dilihat pada gambar berikut.

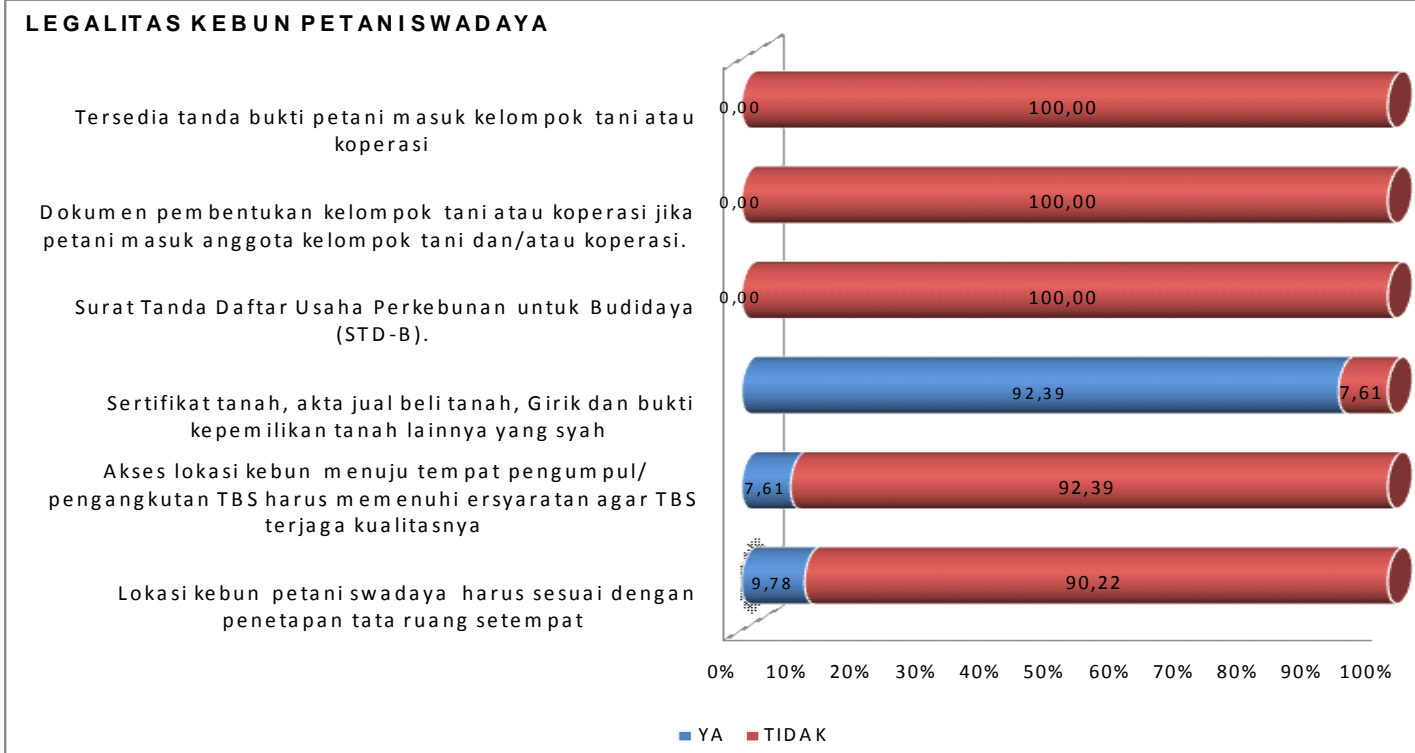

Gambar 1.Prinsip Legalitas Kebun Petani Swadaya

Pada gambar diatas dapat dilihat bahwa ,dari semua indikator yang berada pada kelompok prinsip legalitas kebun petani swadaya, hanya indikator tentang surat tanah yang syah yang dimiliki sebahagian besar $(92,39 \%)$ petani, sedangkan indikator akses tokasi kebun menuju tempat pengumpul/pengangkutan TBS harus memenuhi persyaratan agar TBS terjaga kualitasnya dan indikotor lokasi kebun petani sesuai dengan penetapan tata ruang setempat hanya dimilki sebahagian kecil petani atau kurang dari 10\%. Indikator lainnya pada prinsip ini tidak dimiliki atau tidak ada petani swadaya yang menerapkannya. Artinya dari semua indikator pada prinsip legalitas kebun patani swadaya, hanya satu (16,67\%) indikator yang diterapkan oleh $92,39 \%$ dan dua $(33,33 \%)$ indikator diterapkan sebahagian kecil (lebih kecil dari 10\%) sampel, sedangkan tiga $(50 \%)$ indikator tidak ada petani swadaya yang menerapkannya.

\section{Prinsip Organisasi Petani Dan Pengelolaan Kebun Petani}

Prinsip organisasi petani dan pengelolaan kebun terdiri dari kriteria: (a) swadaya,(b) penerapan pedoman teknis budidaya dan pengankutan kelapa sawit, dimana dari dua kriteria ini terdiri dari 36 indikator. Kriteria swadaya terdiri dari empat sub kriteria dan sepuluh indikator, sub kriteri organisasi kelembagaan kebun petani swadaya, semua indikator pada sub kriteria ini hanya sebanyak $2,17 \%$ petani sawadaya yang memiliki dokumen pembentukan dan susunan pengurus koperasi, sedangkan untuk indikator lainnya seluruh petani pola swadaya tidak memilikinya ,artinya koperasi dan pengurus yang dibentuk oleh sekitar $2,17 \%$ petani swadaya hanya sekedar pembentukan pengurus saja dan tidak ada kegiatan dan rencana kerjanya. Tiga kriteria/sub kriteria lainnya pada prinsip ini hanya $1,09 \%$ petani tersedianya catatan status penyelesaian sengketa dan tersedia peta lokasi yang menjadi sengketa,sedangkan untuk kriteria/sub dan indikator lainnya pada prinsip ini ,semua petani sampel tida memiliki. Artinya petani tidak memiliki dokumen tentang (a) tumpang tidih lahan dengan kegiatan lainnya (b) seketa lahan dan kompensasinya, (c) pemberian informasi kepada pemangku kepantingan dan instansi terkait lainnya. Lebih jelasnya tingkat penerapan indikator petani sawit swadaya berkelanjutan pada kriteria swadaya prinsip organisasi petani dan pengelolaan kebun dapat dilihat pada gambar berikut. 


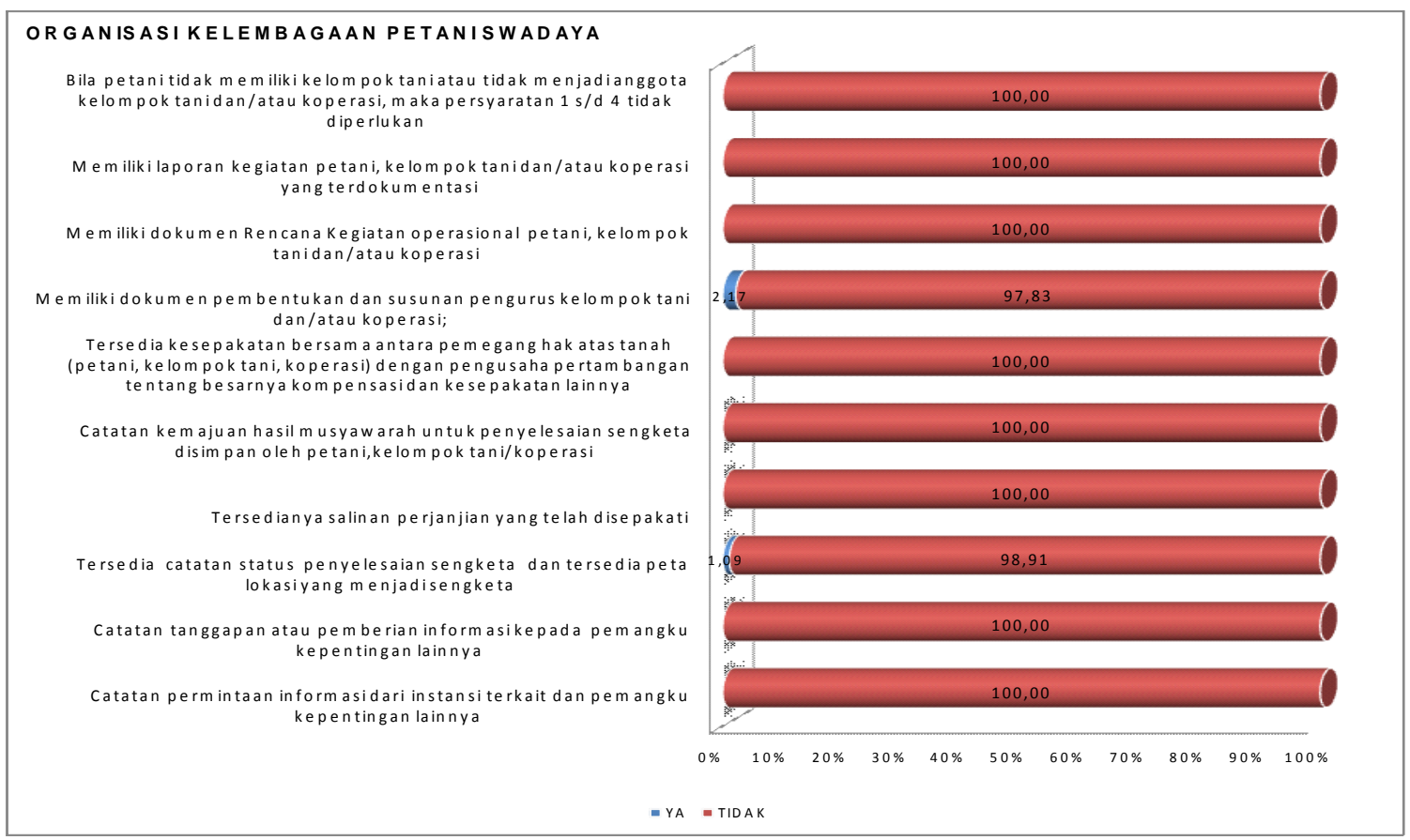

\section{Gambar 2. Prinsip Organisasi Petani Dan Pengelolaan Kebun Petani}

Kriteria penerapan pedoman teknis budidaya dan pengangkutan kelapa sawit, yang juga merupakan kelompok pada prinsip organisasi petani dan pengelolaan kebun petani, terdiri dari sepuluh sub kriteria serta 25 indikator. Untuk lebih jelasnya jumlah atau persentase petani sampel yang sesuai dan yang tidak sesuai dengan indikator pada masing-masing kriteria dapat dilihat pada gambar berikut 
ISBN 978-979-3793-71-9

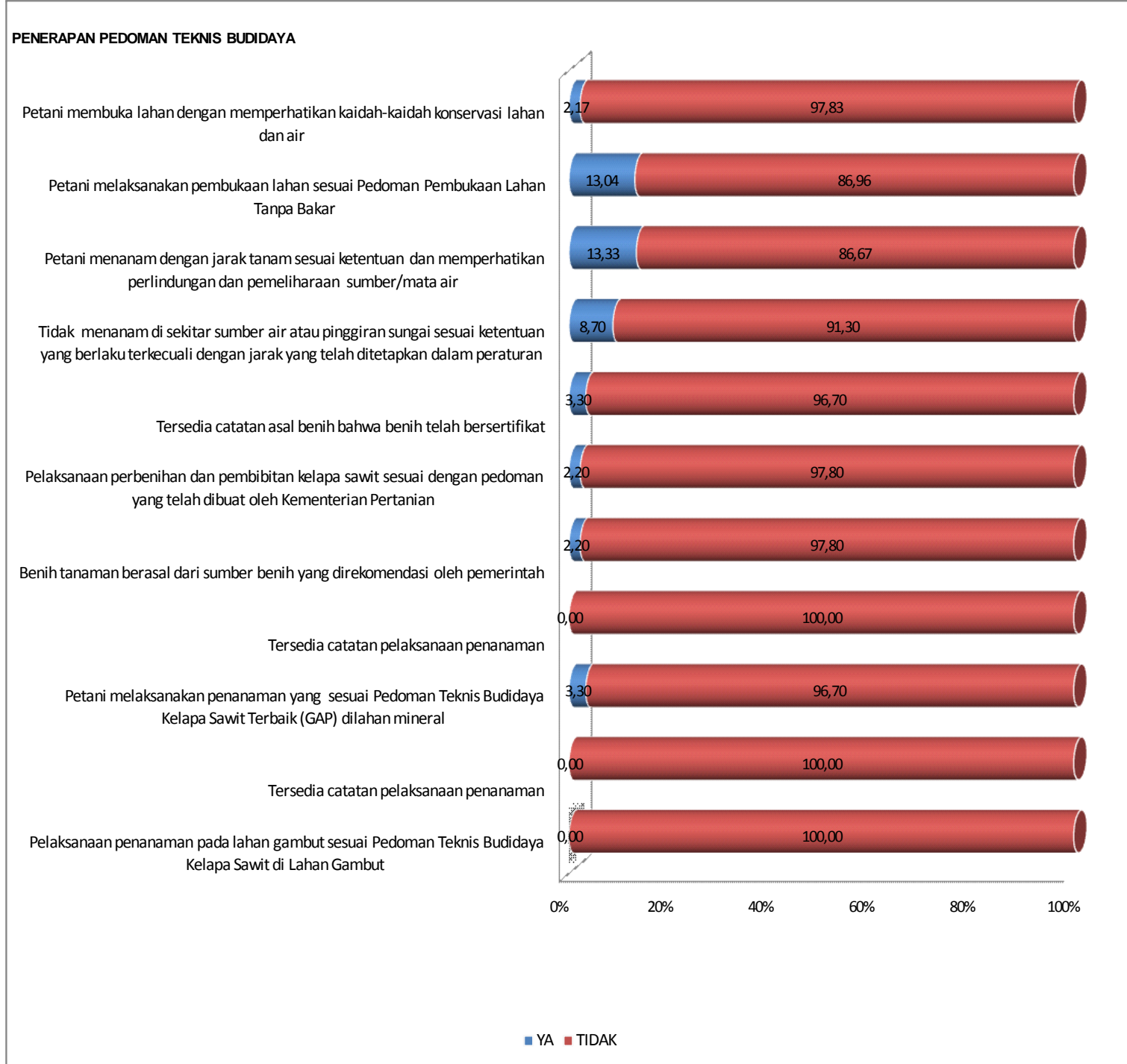

Seminar Nasional “Mitigasi Dan Strategi Adaptasi Dampak Perubahan Iklim Di Indonesia” 


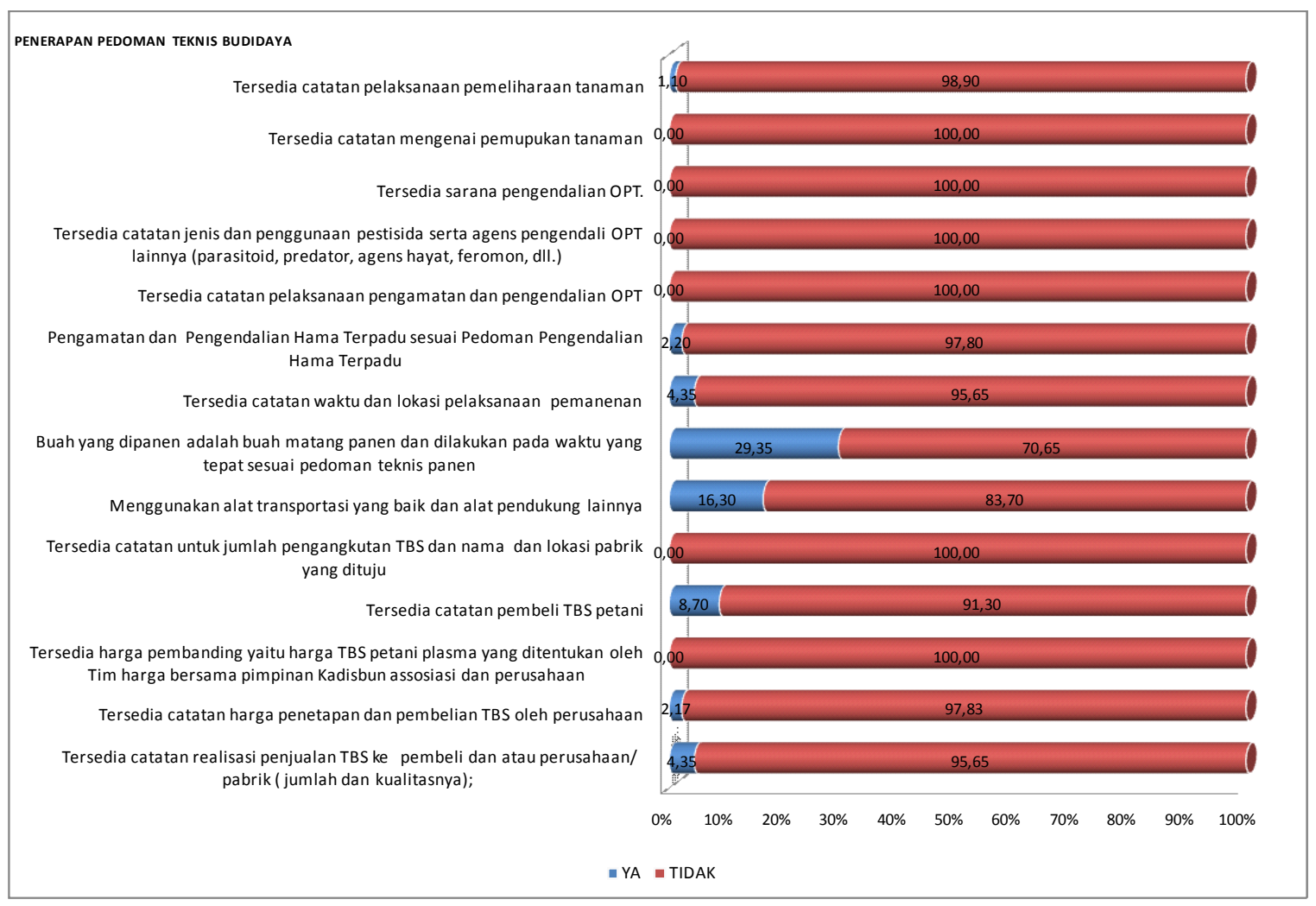

Gambar 3. Penerapan Pedoman Teknis Budidaya

Gambar diatas menunjukan bahwa dari 25 indikator pada kriteri penerapan teknis budidaya dan pengangkutan kelapa sawit, indikator yang terbayak dilakukan petani adalah indikator buah yang dipanen adalah buah matang panen dan dilakukan pada waktu dan cara yang tepat, dimana hanya sebesar $29,35 \%$ petani melakukan nya. Tiga indikator yaitu petani membuka lahan sesuai pedoman pembukaan lahan,petani menanam dengan jarak tanan sesuai ketentuan dan menggunakan alat transportasi yang baik dalam pengankutannya, hanya dilakukan oleh $13 \%$ sampai $16,30 \%$ sampel. Sebelas indikator hanya dijalankan atau dimiliki oleh 2,17\% sampai 8,7\% petani swadaya, sedangkan delapan indikator lainnya tidak ada petani yang menjalankan /memilikinya. Kondisi ini menunjukan bahwa dari semua indikator pada kriteria penerapan pedoman teknis budidaya dan pengangkutan kelapa sawit, jika dirata-ratakan sangat sedikit sekali petani yang sudah melakukan atau memilikinya, ini menunjukan sangat terbatasnya pengetahuan dan kemampuan petani swadaya di kabupaten Inhil serta sarana dan prasarana dalam melaksanakan usaha perkebunan kelapa sawit, sesuai dengan ketentuan yang seharusnya atau perkebunan kelapa sawit yang berkelanjutan. Kondisi seperti ini mengindikasikan sangat tidak siapnya petani swadaya dalam penerapan ISPO, jika tidak cepat direspon, petani akan mengalami kekecewaan karena merima pendapatan yang lebih kecil dari yang diharapkan, artinya mimpi petani tidak memjadi kenyataan dan lahan kelapa sudah ditumbang menjadi lahan sawit, ditambah lagi dengan kondisi seperti ini jika kedepan semua PKS yang ada di Indragiri hilir sudah menerapkan ISPO tidak adalagi PKS yang mau membeli TBS petani.

\section{Prinsip Pengelolaan dan Pemantauan Lingkungan}

Prinsip pengelolaan dan pemantauan lingkungan memiliki tiga kriteria: (a) kewajiban terkait lingkungan, (b)pencegahan dan penanggulangan kebakaran, (c) pelestarian biodeversity dan 5 indikator. Semua indikator dari tiga kriteria ini hanya indikator pencegahan dan penanggulangan kebakaran secara bersama-sama dengan penduduk sekitar dan kantor desa terdekat sesuai pedoman 
yang dilaksaanahan hanya oleh $11,96 \%$ patani swadaya. Indikator mengetahui keberadaan flora flora dan fauna di area kebun dan di sekitar kebun, sebelum dan sesudah dimulainya usaha, yang diketahui oleh $27,17 \%$ petani. Petani yang melaksanakan pencegahan dan penanggulangan kebakaran secara bersama-sama dengan penduduk sekitar dan kantor desa terdekat sesuai pedoman, dimana pada desa ini atas inisiatif dan kebersamaan masyarakat, mereka memiliki kesadaran akan bahaya kebakaran dan mereka mendukung program pemerintah tentang polisi kebakaran hutan dan bekerjasama dengan petugas. Sebesar $27,17 \%$ yang mengetahui flora fauna di kebun dan sekitarnya dulu kebun belum dibuka dan sekarang, petani hanya mengetahui saja dan tidak ada upaya penyelamatan, dimana flora dan fauna itu ada yang mati dan ada yang pindah ke lokasi lain, ini terjadi pada petani yang membuka lahan baru, tapi tidak demikian bagi petani yang hanya alih fungsi lahan dari tanaman lain ke kelapa sawit. Tiga indikator yang lain semua petani tidak memiliki, membuat dan mencatat tentang pengelolaan lingkungan hidup di dalam pengusahaan kebun kelapa sawit.

\section{Prinsip peningkatan usaha secara berkelanjutan}

Prinsip peningkatan usaha secara berkelanjutan, yang terdiri dari satu kriteria usaha berkelanjutan, yang maksud dengan usaha berkelanjutan adalah petani, kelompok tani, koperasi dengan bimbingan lembaga instansi terkait lainnya terus menerus meningkatan kinerja sosial, ekonomi dan lingkungan dengan mengembangkan dan mengimplementasikan recana aksi yang mendukung peningkatan produksi kelapa sawit berkelanjutan. Satu indikator pada kriteria ini, yaitu tersedianya catatan hasil penerapan tindakan perbaikan dan peningkatan kualitas, dari semua petani sampel tidak ada satu pun melakukan pencatatannya. Untuk lebih jelasnya prosentase petani swadaya yang melakukan, mengetahui dan mencatat indikator pada prinsip pengelolaan, pemantauan lingkungan dan prinsip peningkatan usaha berkelanjutan dapat dilihat pada gambar berikut.

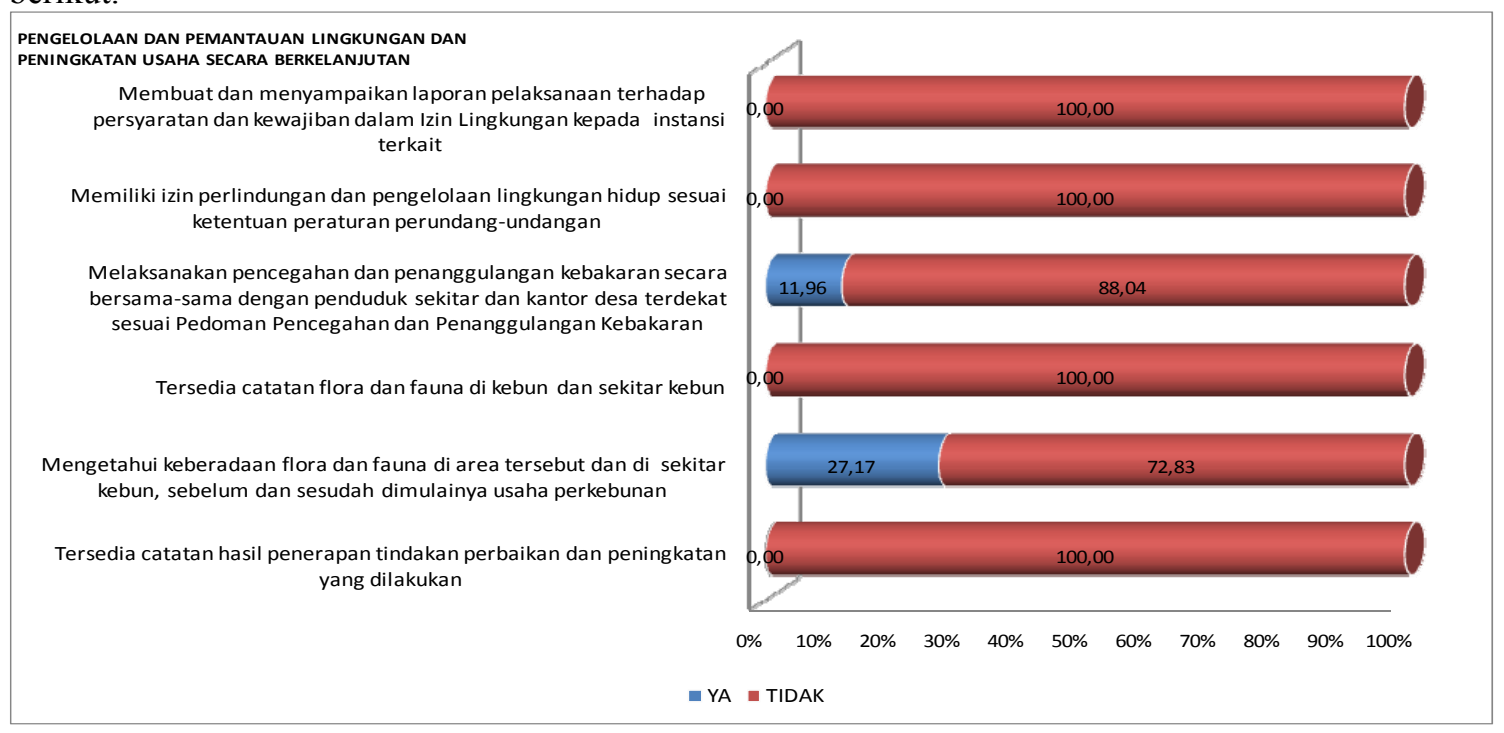

Gambar 4. Prinsip peningkatan usaha secara berkelanjutan

Pada gambar diatas dapat dilihat hanya $11,96 \%$ sampel yang menerapkan dua $(33,33 \%)$ indikator/persyaratan ISPO pada kelompok prinsip pengelolaan pemanfaatan lingkungan dan peningkatan usaha berkelanjutan, sedangkan sebesar $15,21 \%$ sampel hanya menerapkan $16,67 \%$ kriteria. Artinya sebahagian besar (72,21\%)sampel petani swadaya belum menerapkan sama sekali persyaratan ISPO. Pada kriteria ini. Berdasarkan hasil analisis dari semua prinsip, kriteria dan indikator yang telah ditetapkan untuk dilakukan, dimilki dan dicatat oleh petani swadaya Kabupaten Indragiri Hilir dalam memenuhi persyaratan perkebunan kelapa sawit Indonesai 
berkelanjutan ISPO (Indonesia Sustanable Palm Oil), baru sebahagian atau sebesar 51,06 indikator atau persayaratan ISPO tersebut dilakukan/ diterapkan oleh sebahagian kecil petani sawit swadaya, yaitu sebesar $10 \%$ sampai $19,15 \%$ petani swadaya yang baru menjalan atau menerapkan. Ini mengindikasikan bahwa petani kelapa sawit pola swadaya kabupaten Indragiri hilir dengan keterbatasan pengetahuan, keterbatasan kemampuan, keterbatasan sarana dan prasarana, kondisi topografi daerah dan budaya masyarakat, belum siap dalam waktu dekat untuk menerapkan sistin ISPO dalam pengeloaan usaha kebun kelapa sawit. Petani yang sudah menanam sawit dengan bibit non unggul, menanam kebun dipinggir sungai dengan jarak tanaman yang tidak beraturan dan lain sebagainya suatu hal yang sulit untuk diperbaiki atau melanjutkan tanaman tersebut untuk terus dirawat, karena dasar investasi/bahan baku utama yang sudah tidak tepat (bibit non unggul). Penerapan ISPO di Kabupaten Inhil untuk perusahaan dan petani, maka sebahagian besar petani swadaya kabupaten inhil akan terancam kehilangan pendapatan dan kerugian atas investasi yang sudah salah langkah pada awal usaha, yang dilakukan dengan segala keterbatasan. Penerapan ISPO mungkin bisa dilakukan untuk usaha kebun yang akan dibuat dengan terlebih dahulu mensosialisasikan ISPO kepada masyarakat,untuk senahagian besar kebun petani swadaya yang sudah diusahakan diperlukaan kebijakan yang dapat membantu petani.

\section{PENUTUP}

Petani sawit pola swadaya di Kabupaten Indragiri Hilir belum siap untuk penerapan ISPO, karena empat prinsip dan 20 kriteria serta 47 indikator yang ditetapkan sebagai persyaratan ISPO, dari 47 indikator yang ditetapkan pada persayaratan ISPO pola swadaya, hanya sebesar $51,06 \%$ (24) indikator ISPO yang dijalankan petani swadaya. Dari indiKator ISPO yang sudah dijalankan petani swadaya, hanya dijalankan oleh sebahagian kecil petani swadaya, dimana dari seluruh indicator yang sudah dijalankan ini hanya dijalan oleh $10 \%$ sampai $19,15 \%$ petani swadaya.

\section{DAFTAR PUSTAKA}

Badrun. M. 2010. Lintasan 30 Tahun Pengembangan Kelapa Sawit Kementrian Pertanian RI dan Gabungan Pengusaha Kelapa Sawit Indonesia. Direktorat Jendral Perkebunan.

Peraturan Menteri Pertanian Republik Indonesia Nomor 07/Permentan/OT.140/2/2009 tentang pedoman penilaian usaha perkebunan.

Peraturan Menteri Pertanian Republik Indonesia Nomor 19/Permentan/OT.140/3/2011. tentang Pedoman Perkebunan Kelapa Sawit Berkelanjutan di Indonesia (Indonesia Sustainable Palm Oil/ISPO).

Peraturan Menteri Pertanian Republik Indonesia Nomor 11/Permentan/OT.140/3/2015 tentang Sistem Sertifikasi Kelapa Sawit Berkelanjutan Indonesia (Indonesian Sustainable Palm Oil Certification System /ISPO).

Prasetyo. B dan Jannah. L. M. 2011. Metode Penelitian Kuantitatif : Teori dan Aplikasi. Cetakan Kelima. Raja Grafindo Persada. Jakarta

Rosediana S. Anshari G 2013. Environmental and Social Impacts of Oil Palm Cultivation on Tropical peat: a scientific review. Kuala Lumpur. Malaysia. 131 -168 pp.

RSPO. 2007. RSPO Certification System.

RSPO. 2012. Rountable On Sustainable Palm Oil Retrieved from http://www.rspo.org

Sucipto. C. D.. 2011. Vektor Penyakit Tropis. Gosyen Publishing. Yogyakarta.

Seminar Nasional "Mitigasi Dan Strategi Adaptasi Dampak Perubahan Iklim Di Indonesia” 